\title{
Cadherin-11 expression is upregulated in invasive human breast cancer
}

\author{
KAMIL POHLODEK ${ }^{1}$, YEN Y. TAN ${ }^{2}$, CHRISTIAN F. SINGER ${ }^{2}$ and DAPHNE GSCHWANTLER-KAULICH ${ }^{2}$ \\ ${ }^{1}$ Second Department of Gynecology and Obstetrics, Faculty of Medicine, Comenius University of Bratislava, \\ 82606 Bratislava, Slovakia; ${ }^{2}$ Department of Obstetrics and Gynecology, Comprehensive Cancer Center, \\ Medical University of Vienna, A-1090 Vienna, Austria
}

Received March 16, 2016; Accepted August 26, 2016

DOI: $10.3892 / \mathrm{ol} .2016 .5236$

\begin{abstract}
Loss of expression of cadherin-11 protein is correlated with a loss of epithelial phenotype and a gain in tumor cell proliferation and invasion. It has been hypothesized that cadherin-11 may be a molecular marker for a more aggressive subtype of breast cancer. The present study examined the expression of the mesenchymal gene/protein cadherin-11 in malignant, benign and healthy breast cancer samples. A paraffin-embedded tissue microarray of both malignant and benign/healthy breast tumor was used. Clinicopathological parameters, including age, grading, tumor size, hormone receptors and HER2 receptors status were obtained from patient medical records. Expression of cadherin-11 was analyzed using the monoclonal mouse anti cadherin-11 IgG2B clone. Total RNA was extracted from each breast cancer sample and subjected to semi-quantitative RT-PCR analysis for cadherin-11. Cadherin-11 was detected in 80/82 malignant breast cancer samples and in 33/70 non-malignant tissue samples. Cadherin-11 expression was observed to be predominantly localized to the membrane of tumor cells. When compared to healthy breast tissue biopsies, both cadherin-11 mRNA and protein were demonstrated to be significantly overexpressed in breast carcinoma $(\mathrm{P}=0.040$ and $\mathrm{P}<0.0001$, respectively). Within malignant tumors, however, protein expression was not identified to be associated with other clinicopathological parameters. Our results indicate that cadherin-11 expression is upregulated in malignant human breast cancer.
\end{abstract}

\section{Introduction}

Cadherins belong to a family of transmembraneous adhesion molecules that are important in maintaining cell polarity and

Correspondence to: Dr Kamil Pohlodek, Second Department of Gynecology and Obstetrics, Faculty of Medicine, Comenius University of Bratislava, Ružinovská 6, 82606 Bratislava, Slovakia E-mail: kamil.pohlodek@fmed.uniba.sk

Key words: cadherin-11, breast cancer, normal breast tissue tissue integrity (1). They can mediate calcium-dependent cell-to-cell adhesion by interacting with the cytoplasmatic catenins, $\alpha, \beta$, and $\gamma(2,3)$. The catenins link cadherins to the actin cytoskeleton, but also have signaling functions of their own. Over the years, $>20$ types of cadherins have been identified and characterized, including the original E-, P- and $\mathrm{N}$-cadherin (Type I), and cadherins 5 to 12 (Type II) (1-4). While the two subgroups share structural similarities, they exhibit surprisingly little sequence homology. Cadherins are involved in normal mammary gland development and function, and they appear to influence breast cancer and its clinical outcome (1,3-6). Berx and van Roy (7) reviewed the role of cadherins in malignant disease, and it has been demonstrated that loss of E-cadherin expression was associated with increased invasiveness and decreased differentiation. Interestingly, re-induction of E-cadherin in invasive breast cancer cells did not result in a less aggressive behavior in vitro, thereby suggesting that E-cadherin is rather an indicator of a more invasive phenotype than a causative factor $(3,5,8)$.

Cadherin-11, also known as OB-cadherin was first identified in mouse osteoblasts and is normally expressed in cells with a mesenchymal phenotype, including the mesenchyme of the kidney and brain during development $(8,9)$. Cadherin-11 is also expressed in cartilage synoviocytes and is an important mediator of the synoviocyte reaction that characterizes rheumatoid arthritis (10). In the adult, cadherin-11 is strongly expressed in bone as well as certain cancers that metastasize to bone (11). While the exact expression profile of cadherin-11 in healthy mammary gland is not known, it has been shown that it interacts with the fibroblast growth factor (FGF) signaling pathway $(2,8,12)$, and thus modulates the response to growth factors. Cadherin-11 is typically expressed in many types of condensing mesenchyme and when expressed in epithelium, EMT is thought to have occurred (12-17). It may also provide the cell with an ability to establish itself into the bone environment $(5,11)$. The majority of patients that succumb to breast (or prostate) cancer have metastases to the skeleton. It is possible that these cadherin-11-expressing tumor cells activate either osteoclasts or osteoblasts, depending on the type of cancer metastasis, leading to bone remodeling (11).

While the precise role of cadherins in cancer remains unclear, they are important in the basic events and processes in breast cancer tumorigenesis $(4,12)$. Several events in 
tumorigenesis are strongly connected to changes in cadherin expression (14-18). One example is cadherin switching, where cadherins change from those expressed in epithelial cells to those predominant in mesenchymal cells (8). This event is part of a process that is vital to malignant change, the epithelial-mesenchymal transition (EMT). EMT is a key biologic process that was initially identified as a developmental program that enables polarized epithelial cells to acquire a motile mesenchymal phenotype $(13-17,19,20)$. This transition results in a more invasive and metastatic phenotype $(15-17,19)$. Research suggests that cadherin switching is required for increased motility but not for the morphological changes that accompany EMT $(13,19)$. The reverse process of EMT, the mesenchymal-epithelial transition (MET) involves the conversion of mesenchymal cells to their epithelial derivatives (14). In carcinoma progression, reactivation of the EMT program promotes tumor metastasis by driving tumor cell invasion and enhancing tumor cell survival $(16,17)$. These changes are highly dynamic and many intermediate phenotypes exist. Dubois-Marshall et al (16) described two distinct possible mechanisms of EMT arising in breast cancer, one of which is uncoupled from cadherin switching. Some difficulty lies in the fact that it is not yet fully understood how cadherins expression profiles change in EMT. This emanates from the fact that there are multiple ways to regulate cadherin expression, and many, but not all of these overlap (2). Recently, cadherins were demonstrated to regulate stem cell maintenance and differentiation (20). The use of mesenchymal stem cells for tissue repair requires the migration and homing to the site of damaged tissue and it has been shown that both the migratory and proliferation potential of these cells are affected by cadherin-2 and cadherin-11 (20).

Pishvaian et al (6) have demonstrated that cadherin-11 mRNA and protein, as well as a cadherin-11 variant mRNA are expressed in invasive and poorly differentiated breast cancer cell lines. In these cells, cadherin-11 is localized to the cell membrane in a detergent-soluble complex, where it associates with $\alpha$ and $\beta$-catenin, and may facilitate tumor cell invasion and metastasis. Assefnia et al and Dakshanamurthy et al $(21,22)$ demonstrated that cadherin-11 is increased in early stages of human breast cancer and in other malignancies. When compared to healthy breast tissue, cadherin-11 was markedly elevated in DCIS and also in the stroma of invasive breast cancers compared to normal stroma. While this seems counter-intuitive at first, it illustrates that the functional diversity of cadherins in physiological cell is also reflected in processes connected to malignant disease.

There is paucity of studies evaluating cadherin-11 expression in human invasive breast cancer. The aim of the present study was to investigate cadherin-11 expression in malignant breast tissue samples and benign and/or healthy breast tissue samples. The expression was then correlated with several clinicopathological parameters.

\section{Materials and methods}

Patient samples. Human breast tissue microarray (TMA) slides were obtained from US Biomax Inc. (Rockville, MD, USA). These TMAs consists of malignant and benign breast tumors, and healthy breast tissue adjacent to a malignant tumor or from women undergoing reduction mammoplasty. Clinicopathological information was obtained, including age, tumor grade, tumor size and histology. Hormone receptor status, e.g., estrogen, progesterone and HER2, as well as cadherin-11 expression were analyzed using immunohistochemistry (IHC).

Immunohistochemistry for cadherin-11. Tissue sections of paraffin-embedded formalin-fixed tissue blocks were deparaffinized with xylene for $5 \mathrm{~min}$ each, followed by two washes with $100 \%$ ethanol for $10 \mathrm{~min}$. The slides were then incubated in $95 \%$ ethanol for another $10 \mathrm{~min}$ and washed with $\mathrm{dH}_{2} \mathrm{O}$ twice for $5 \mathrm{~min}$. Antigen retrieval was performed by placing slides in $10 \mathrm{mmol} / \mathrm{l}$ citrate buffer ( $\mathrm{pH} \mathrm{6.0)}$ and microwave treatment for $15 \mathrm{~min}$. Tissue sections were cool down to room temperature (RT), washed in phosphate-buffered saline (PBS) and distilled water. Afterwards, sections were blocked with Ultra V Block (Lab Vision, Westinghouse Drive, Fremont, CA, USA) for $4 \mathrm{~min}$. After a consecutive PBS wash, slides were incubated with the monoclonal Mouse anti cadherin-11 IgG2B Clone \# 283416 Catalog Number: MAB1790 (R\&D Systems). Negative controls were performed on all tissue sections by replacing primary antibodies with diluted isotype immunoglobulin (ImmunoCruz ${ }^{\mathrm{TM}}$ Staining system, Santa Cruz Biotechnology). Then the slides were incubated with goat anti-polyvalent and streptavidin-HRP (both Lab Vision) for $60 \mathrm{~min}$, followed by an incubation with 3-amino-9-ethylcarbazole (AEC). Finally, slides were washed in PBS, counterstained with hematoxylin for $5 \mathrm{sec}$ and cover-slipped.

Semi-quantitative reverse transcription polymerase chain reaction (RT-PCR) for Cadherin-11. A total of 0.5-1 $\mu \mathrm{g}$ of total RNA was extracted from each of the breast cancer samples, subsequently subjected to DNase (RNase-Free DNase Set; Qiagen, Hilden, Germany) treatment and then incubated with $0.5 \mu \mathrm{g} / \mu \mathrm{l}$ random hexamers (Promega Corp., Madison, WI, USA). The final volume was adjusted to $5 \mu$ l with diethyl pyrocarbonate-treated double distilled water (DEPC-treated $\mathrm{dd}_{2} \mathrm{O}$ ), before being heat-denatured at $70^{\circ} \mathrm{C}$ for $5 \mathrm{~min}$ and chilled on ice. The samples were then added to a reaction mix consisting of $4 \mu \mathrm{l}$ of $5 \mathrm{X}$ RT-buffer $(250 \mathrm{mM}$ Tris-HCl, $\left.\mathrm{pH} 8.3,375 \mathrm{mM} \mathrm{KCl}, 15 \mathrm{mM} \mathrm{MgCl} \mathrm{m}_{2}\right), 2 \mu \mathrm{l} \mathrm{dNT}$ mix stock solution (10 mM each Pharmacia Biotech, Uppsala, Sweden), $1 \mu 1$ RNase inhibitor (Applied Biosystems, Vienna, Austria), $1 \mu \mathrm{l}$ dithiothreitol (DTT), and $1 \mu \mathrm{l}$ MMLV (Moloney murine leukemia virus)-RT (200 U/ $\mu 1$, Amersham Bioscience Ltd.). The reaction mix was vortexed and centrifuged briefly before being incubated at $37^{\circ} \mathrm{C}$ for $1 \mathrm{~h}$. The reaction was stopped by heating to $80^{\circ} \mathrm{C}$ for $10 \mathrm{~min}$. The tubes were chilled briefly on ice before they were centrifuged and stored at $-20^{\circ} \mathrm{C}$.

PCR was performed by adding $20 \mu \mathrm{l}$ reaction mix to $2.5 \mu \mathrm{l}$ 10X PCR-buffer, $2 \mu \mathrm{l}$ dNTP mix (10 mM each; New England Biolabs, Hertfordshire, UK), $0.25 \mu \mathrm{l}$ primer (100 $\mu \mathrm{M}), 5 \mu \mathrm{l}$ Taq polymerase $(5 \mathrm{U} / \mathrm{ml})$ to the cadherin-11 primers (primer sequences: Forward, 5'-ACC AGA TGT CTG TGT CAG A-3' and reverse, 3'-GTC ATC CTT GTC ATC TGC A-5'. The gene GAPDH (primer sequences: Forward, 5'-GAA GGT GAA GGT CGG AGT C-3' and reverse, 3'-GAA GAT GGT GAT GGG ATT TC-5') was used as a reference for normalization. A total volume of $45 \mu \mathrm{l}$ was reached by adding DEPC-treated $\mathrm{dd}_{2} \mathrm{O}$. Cycling conditions were as follows: 
Table I. Patients characteristics.

\begin{tabular}{|c|c|c|c|}
\hline Characteristic & $\begin{array}{l}\text { Malignant } \\
\text { tumor } \\
(n=82)\end{array}$ & $\begin{array}{l}\text { Benign tumors } \\
\text { and/or normal } \\
\text { tissue }(n=70)\end{array}$ & P-value \\
\hline $\begin{array}{l}\text { Median age } \\
\text { (range), years }\end{array}$ & $51(42-62)$ & $48(41-55)$ & \\
\hline Cadherin-11 ${ }^{\mathrm{a}}, \mathrm{n}(\%)$ & & & $<0.0001$ \\
\hline 0 & $2(2.4)$ & $37(52.9)$ & \\
\hline+ & $21(25.6)$ & $13(18.6)$ & \\
\hline++ & $34(41.5)$ & $12(17.1)$ & \\
\hline+++ & $25(30.5)$ & $8(11.4)$ & \\
\hline Histology, n (\%) & & & N/A \\
\hline Invasive ductal & $62(75.6)$ & $\mathrm{N} / \mathrm{A}$ & \\
\hline Invasive lobular & $3(3.7)$ & & \\
\hline Other & $17(20.7)$ & & \\
\hline Tumor grade, n (\%) & & & N/A \\
\hline $\mathrm{G} 1$ & $15(18.3)$ & & \\
\hline $\mathrm{G} 2$ & $44(53.7)$ & & \\
\hline G3 & $14(17.0)$ & & \\
\hline Unknown & $9(11.0)$ & $\mathrm{N} / \mathrm{A}$ & \\
\hline Tumor size, n (\%) & & & N/A \\
\hline $\mathrm{T} 1$ & $20(24.4)$ & & \\
\hline $\mathrm{T} 2$ & $45(56.1)$ & & \\
\hline $\mathrm{T} 3$ & $16(19.5)$ & N/A & \\
\hline $\mathrm{T} 4$ & $1(1.2)$ & & \\
\hline $\mathrm{ER}, \mathrm{n}(\%)$ & & & N/A \\
\hline 0 & $16(19.5)$ & & \\
\hline $5 \%$ & $10(12.2)$ & & \\
\hline $5-10 \%$ & $8(9.8)$ & & \\
\hline$>10 \%$ & $40(48.8)$ & & \\
\hline Unknown & $8(9.8)$ & N/A & \\
\hline PR, n (\%) & & & $\mathrm{N} / \mathrm{A}$ \\
\hline 0 & $22(26.8)$ & & \\
\hline $5 \%$ & $12(14.6)$ & & \\
\hline $5-10 \%$ & $16(19.5)$ & & \\
\hline$>10 \%$ & $14(17.1)$ & & \\
\hline Unknown & $18(22.0)$ & N/A & \\
\hline HER2, n (\%) & & & N/A \\
\hline Positive $^{b}$ & $22(26.8)$ & & \\
\hline Negative & $60(73.2)$ & N/A & \\
\hline
\end{tabular}

${ }^{a}$ Cadherin 11 immunohistochemical scoring: Negative (0); low (+); intermediate $(++)$; high positive $(+++)$. ${ }^{\text {H} H E R} 2$ positive equals a score of IHC $3+$. ER, estrogen receptor; PR, progesterone receptor; HER2, human epidermal growth factor receptor 2 .

Depending on the primers, 25-35 cycles were carried out of $94^{\circ} \mathrm{C}$ for $1 \mathrm{~min}, 68^{\circ} \mathrm{C}$ for $2 \mathrm{~min}, 72^{\circ} \mathrm{C}$ for $2 \mathrm{~min}$, with an extension of $5 \mathrm{sec}$, with each subsequent cycle. $\mathrm{ddH}_{2} \mathrm{O}$ was used instead of total RNA for negative controls. Agarose gel electrophoresis was performed by adding $20 \mu \mathrm{l}$ of each of the PCR products and subjecting them to $1.2 \%$ NuSieve $^{\circledR}$ (Lonza
A



B

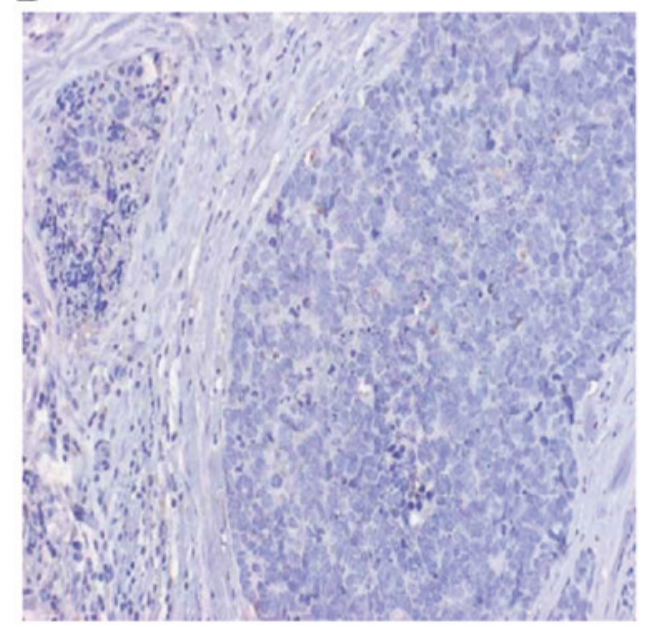

Figure 1. Cadherin-11 protein expression in (A), malignant breast cancer tissue and in (B) normal breast tissue. Immunohistochemical staining with MAB1790. Magnification, (A) x400 and (B) x100. Cadherin-11 is (A) localized on the cell membrane of malignant cells (red color), and (B) absent in normal tissue.

Ltd., Basel, Switzerland) 3:1 agarose gel electrophoresis in $1 \mathrm{X}$ TBE buffer, separated by applying a constant voltage at $80 \mathrm{~V}$ for $1-2 \mathrm{~h}$. DNA bands were then visualized by ethidium bromide, using UV transilluminator (Syngene ${ }^{\circledR}$, Cambridge, UK). Band size was determined by a co-loaded DNA size marker.

Evaluation of immunohistochemical staining and statistical analysis. Immunostained slides were scored under a microscope (Olympus BX51; Olympus, Tokyo, Japan). The staining intensity of hormone receptors was scored according to Remmele et al (23). The HER2 receptor status has been evaluated according to standardized assessment (24). Only slides with a IHC $3+$ status of HER 2 receptors were categorized as positive. Chi-square and Student's t-test were used to compare cadherin-11 protein expression and age. Associations between cadherin-11 and clinical-pathological parameters were analyzed using Pearson's rho correlation test (2-sided). For all analyses, $\mathrm{P}<0.05$ was considered to indicate a statistically significant difference. Data were analyzed using SAS version 8.1 (SAS Institute Inc., Cary, NC, USA). 
Table II. Correlation between cadherin-11 protein expression and clinicopathological parameters.

\begin{tabular}{|c|c|c|c|c|c|c|}
\hline Parameter & Age & Grading & Tumor size & ER & PR & HER2 \\
\hline \multicolumn{7}{|l|}{ Cadherin-11 } \\
\hline Correlation coeff. & -0.109 & -0.034 & 0.340 & 0.034 & 0.029 & 0.128 \\
\hline Sig. (2-tailed) & 0.331 & 0.762 & 0.701 & 0.760 & 0.795 & 0.252 \\
\hline \multicolumn{7}{|l|}{ Age } \\
\hline Correlation coeff. & & 0.107 & 0.071 & -0.125 & -0.167 & -0.017 \\
\hline Sig. (2-tailed) & & 0.340 & 0.525 & 0.263 & 0.133 & 0.882 \\
\hline \multicolumn{7}{|l|}{ Grading } \\
\hline Correlation coeff. & & & -0.185 & 0.043 & 0.049 & 0.081 \\
\hline Sig. (2-tailed) & & & 0.097 & 0.703 & 0.664 & 0.470 \\
\hline \multicolumn{7}{|l|}{ Tumor size } \\
\hline Correlation coeff. & & & & 0.125 & 0.199 & 0.057 \\
\hline Sig. (2-tailed) & & & & 0.173 & 0.074 & 0.610 \\
\hline \multicolumn{7}{|l|}{ ER } \\
\hline Correlation coeff. & & & & & -0.169 & 0.036 \\
\hline Sig. (2-tailed) & & & & & 0.129 & 0.748 \\
\hline \multicolumn{7}{|l|}{ PR } \\
\hline Correlation coeff. & & & & & & 0.138 \\
\hline Sig. (2-tailed) & & & & & & 0.215 \\
\hline
\end{tabular}

ER, estrogen receptor; PR, progesterone receptor; HER2, human epidermal growth factor receptor 2.

\section{Results}

A total of 82 malignant tumor samples and 70 healthy breast tissue and benign breast lesions were analyzed by IHC and semi-quantitative RT-PCR. The patient tumor characteristics are shown in Table I. The median age of the patients with malignant tumors was 51 years, and median age of patients with benign or healthy tissue was 48 years. The difference in median age was not statistically significant. Of the malignant tumors, $75 \%(n=62)$ were infiltrating ductal carcinomas, and the remaining histological types included infiltrating lobular carcinomas $(n=3)$ and otherwise specified $(n=17)$. Regarding tumor size, $56 \%$ of malignant tumors were stage $2(n=45)$, $24.4 \%$ were stage $1(n=20), 19.5 \%$ were stage T3 $(n=16)$, and $1 \%$ were stage $4(\mathrm{n}=1)$. The majority of tumors were grade 2 $(53.7 \%, \mathrm{n}=44)$, followed by grade $1(18.3 \%, \mathrm{n}=15)$ and Grade 3 $(17 \%, \mathrm{n}=14)$. In 9 cases $(11 \%)$, the tumor grades were unknown. The estrogen receptor status was positive in $71 \%$ of the samples $(n=58)$, negative in $19.5 \%$ of cases $(n=16)$, with $9.8 \%(n=8)$ unknown. The progesterone receptor status was positive in 42 $(51.2 \%)$ cases, negative in $26.8 \%(n=22)$ cases and $22 \%$ were unknown. The HER 2 receptor status was positive in 22 cases (26.8\%) were HER2 receptors evaluated as positive and negative in 60 cases $(73.2 \%)$.

Fig. 1 shows the IHC results for cadherin-11. In malignant tissue samples, 25 cases $(30.5 \%)$ exhibited strong positivity for cadherin-11, 34 cases $(41.5 \%)$ had moderate positivity, and weak positivity in another 21 cases $(25.6 \%)$. Of 82 cases, only two $(2.4 \%)$ were negative for cadherin-11. As for benign/healthy samples, only 8 cases $(11.4 \%)$ exhibited strong positivity for cadherin-11, 12 (17.1\%) were moderate positive, and 13

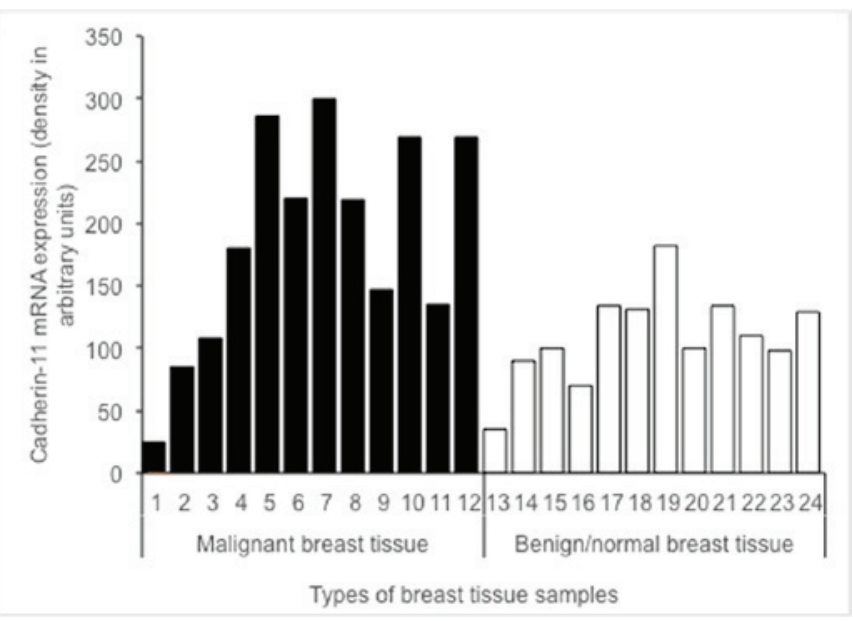

Figure 2. Cadherin-11 mRNA expression in malignant breast tissue samples (black lanes 1-12) and benign/normal breast tissue samples (white lanes 13-24). On the $x$-axis are each group of breast tissue samples and the $y$-axis presents the density in arbitrary units. The differences in mRNA expression between malignant, and benign and/or normal tissue samples were statistically significant $(\mathrm{P}=0.040)$.

(18.6\%) were weak positive. However, more benign/normal tissues tested negative for cadherin-11 than malignant tumors (52.9 vs. $2.4 \%$, respectively). This difference was statistically significant $(\mathrm{P}<0.0001)$.

Correlations between cadherin-11 protein expression and other clinical-pathological parameters are shown in Table II. The expression of cadherin-11 protein was not correlated with patient age, tumor size, grading, or hormone receptors status. 
The expression of cadherin-11 mRNA in malignant tissues (black lanes 1-12) vs. benign/healthy tissues (white lanes 13-24) is shown in Fig. 2. The difference in cadherin-11 mRNA levels between malignant, and benign and/or healthy tissue samples was statistically significant $(\mathrm{P}=0.040)$.

\section{Discussion}

The present study demonstrates a significant difference in both mRNA transcription and protein expression of cadherin-11 in malignant breast tissue, when compared to benign and/or healthy tissue. These findings are consistent with past research and further emphasize the role of cadherins in the fundamental mechanics of the disease $(3,5,6,13,19)$. Furthermore, this also points to the suspected role of cadherin-11 in EMT (12-17,19).

Our results are in agreement with the data of Pishvaian et al (6), who examined the expression of cadherin-11 in breast cancer cell lines and demonstrated that cadherin-11 mRNA and protein were expressed in the most invasive cell lines, but not in any of the noninvasive cell lines. Based on these results, it is anticipated that cadherin-11 expression may be well correlated with the invasive phenotype in cancer cells and could serve as a molecular marker for the more aggressive, invasive subset of breast tumors. Pishvaian et al (6) reported that cadherin-11 expression was significantly upregulated in malignant tissue samples and that it was localized on the cell membrane of the malignant cells, which is also in line with the results presented in Fig. 1. Similarly, the difference in mRNA expression in malignant and benign tissue samples was statistically significant ( $\mathrm{P}=0.040)$ in the present study (Fig. 2). Cadherin-11 was preferentially expressed in basal-like breast cancer (13). The differences between expression of cadherin-11 protein and grading or hormone receptors status were not statistically significant in our study. There was also no correlation between estrogen and progesterone receptors in malignant breast tissue samples (Table II). The lack of correlation may be due to the median age of the sample group (51 years), since older, post-menopausal women are more likely to develop estrogen receptor positive breast cancer. Previous studies have demonstrated that there is no relationship between age and progesterone receptor positivity (25-27).

The present study was limited in several ways. Firstly, the control group consisted of tissue samples with undefined benign pathologies, which may influence the expression profile of cadherins. Secondly, the protein expression of cadherin-11 was performed using immunohistochemistry, which is subjective, and proper evaluation of the score is lacking. We also lacked clinical data on bone metastasis, which could have proven relevant in this study.

The current study succeeded in demonstrating that cadherin-11 expression is upregulated in invasive human breast cancer. We hypothesize that the expression confers a more mesenchymal cellular phenotype, which promotes invasion and metastasis in invasive tumors.

Cadherin-11 is a major therapeutic target in rheumatoid arthritis $(10,21)$. Using a new proteochemometric computational drug repurposing method, it was identified that the drug celecoxib, a United States Food and Drug Administration approved drug, and 2,5-dimethyl-celecoxib, a celecoxib analogue without cyclooxygenase 2 inhibitory activity, had the structural potential to bind cadherin-11 (22). As cadherin-11 may be an important target in cancer progression $(21,28)$, this finding could potentially translate into clinical application in cancer therapy. In conclusion, our results indicate that cadherin-11 expression is upregulated in malignant human breast cancer. Based on the fact that cadherin-11 is typically expressed in cells of mesenchymal origin, this suggests that EMT took place. These data suggest that cadherin-11 is important for malignant progression and is a potential therapeutic target in breast cancer.

\section{References}

1. Knudsen KA and Wheelock MJ: Cadherins and the mammary gland. J Cell Biochem 95: 488-496, 2005.

2. Andrews JL, Kim AC and Hens JR: The role ad function of cadherins in the mammary gland. Breast Cancer Res 14: 203, 2012.

3. Farina AK, Bong YS, Feltes CM and Byers SW: Post-transcriptional regulation of cadherin-11 expression by GSK-3 and beta-catenin in prostate and breast cancer cells. PLoS One 4: e4797, 2009.

4. Albergaria A, Ribeiro AS, Vieira AF, Sousa B, Nobre AR, Seruca R, Schmitt FC and Paredes J: P-cadherin role in normal breast development and cancer. Int J Dev Biol 55: 811-822, 2011.

5. Tamura D, Hiraga T, Myoui A, Yoshikawa $H$ and Yoneda $T$ : Cadherin-11-mediated interactions with bone marrow stromal/osteoblastic cells support selective colonization of breast cancer cells in bone. Int J Oncol 33: 17-24, 2008.

6. Pishvaian MJ, Feltes CM, Thompson P, Bussemakers MJ, Schalken JA and Byers SW: Cadherin-11 is expressed in invasive breast cancer cell lines. Cancer Res 59: 947-952, 1999.

7. Berx G and van Roy F: Involvement of members of the cadherin superfamily in cancer. Cold Spring Harb Perspect Biol 1: a003129, 2009.

8. Maeda M, Johnson KR and Wheelock MJ: Cadherin switching: Essential for behavioral but not morphological changes during epithelium-to-mesenchyme transition. J Cell Sci 118: 873-887, 2005.

9. Kalluri R and Weinberg RA: The basics of epithelial-mesenchymal transition. J Clin Invest 119: 1420-1428, 2009.

10. Lee DM, Kiener HP, Agarwal SK, Noss EH, Watts GF, Chisaka O, Takeichi $\mathrm{M}$ and Brenner MB: Cadherin-11 in synovial lining formation and pathology in arthritis. Science 315: 1006-1010, 2007.

11. Huang CF, Lira C, Chu K, Bilen MA, Lee YC, Ye X, Kim SM, Ortiz A, Wu FL, Logothetis CJ, et al: Cadherin-11 increases migration and invasion of prostate cancer cells and enhances their interaction with osteoblasts. Cancer Res 70: 4580-4589, 2010.

12. Nieto MA: Epithelial-mesenchymal transitions in development and disease: Old views and new perspectives. Int J Dev Biol 53: 1541-1547, 2009.

13. Sarrió D, Rodriguez-Pinilla SM, Hardisson D, Cano A, Moreno-Bueno G and Palacios J: Epithelial-mesenchymal transition in breast cancer relates to the basal-like phenotype. Cancer Res 68: 989-997, 2008.

14. Chao YL, Shepard CR and Wells A: Breast carcinoma cells re-express E-cadherin during mesenchymal to epithelial reverting transition. Mol Cancer 9: 179, 2010.

15. Clevers $H$ and Nusse $R:$ Wnt/ß-catenin signaling and disease. Cell 149: 1192-1205, 2012.

16. Dubois-Marshall S, Thomas JS, Faratian D, Harrison DJ and Katz E: Two possible mechanisms of epithelial to mesenchymal transition in invasive ductal breast cancer. Clin Exp Metastasis 28: 811-818, 2011.

17. Aceto N, Toner M, Maheswaran S and Haber D: En route to metastasis: Circulating tumor cell clusters and epithelial-to-mesenchymal transition. Trends in Cancer 1: 44-52, 2015.

18. Satcher RL, Pan T, Cheng CJ, Lee YC, Lin SC, Yu G, Li X, Hoang AG, Tamboli P, Jonasch E, et al: Cadherin-11 in renal cell carcinoma bone metastasis. PLoS One 9: e89880, 2014.

19. Li Y, Chao F, Huang B, Liu D, Kim J and Huang S: HOXC8 promotes breast tumorigenesis by transcriptionally facilitating cadherin-11 expression. Oncotarget 5: 2596-2607, 2014.

20. Alimperti S and Andreadis ST: CDH2 and CDH11 act as regulators of stem cell fate decisions. Stem Cell Res 14: 270-282, 2015. 
21. Assefnia S, Dakshanamurthy S, Guidry Auvil JM, Hampel C, Anastasiadis PZ, Kallakury B, Uren A, Foley DW, Brown ML, Shapiro L, et al: Cadherin-11 in poor prognosis malignancies and rheumatoid arthritis: Common target, common therapies. Oncotarget 5: 1458-1474, 2014.

22. Dakshanamurthy S, Issa NT, Assefnia S, Seshasayee A, Peters OJ, Madhavan S, Uren A, Brown ML and Byers SW: Predicting new indications for approved drugs using a proteochemometric method. J Med Chem 55: 6832-6848, 2012.

23. Remmele W and Schicketanz KH: Immunohistochemical determination of estrogen and progesterone receptor content in human breast cancer. Computer-assisted image analysis (QIC score) vs. subjective grading (IRS). Pathol Res Pract 189: 862-866, 1993.

24. Hicks DG and Schiffhauer L: Standardized assessment of the HER2 status in breast cancer by immunohistochemistry. Lab Med 42: 459-467, 2011.
25. Savci-Heijink CD, Halfwerk H, Hooijer GK, Horlings HM, Wesseling $\mathbf{J}$ and van de Vijver MJ: Retrospective analysis of metastatic behaviour of breast cancer subtypes. Breast Cancer Res Treat 150: 547-557, 2015.

26. Salmen J, Neugebauer J, Fasching PA, Haeberle L, Huober J, Wöckel A, Rauh C, Schuetz F, Weissenbacher T, Kost B, et al: Pooled analysis of the prognostic relevance of progesterone receptor status in five German cohort studies. Breast Cancer Res Treat 148: 143-151, 2014.

27. Sun JY, Wu SG, Li FY, Lin HX and He ZY: Progesterone receptor loss identifies hormone receptor-positive and HER2-negative breast cancer subgroups at higher risk of relapse: A retrospective cohort study. Onco Targets Ther 9: 1707-1713, 2016.

28. van Roy F: Beyond E-cadherin: Roles of other cadherin superfamily members in cancer. Nat Rev Cancer 14: 121-134, 2014 